\section{BRAND COMMUNICATION AS A SOCIAL PHENOMENON}

Mykhailo POPLAVSKY I

Doctor of Pedagogics, Professor

Kyiv National University

of Culture and Arts

36 Ye. Konovalets Str.,

01133, Kyiv, Ukraine

e-mail:pomm20180326@gmail.com

ORCID ID 0000-0002-8234-8064

(c) Poplavskyi M., 2018

Social conditionality of the object interaction, its emotional evaluation, as well as the motivation for further interaction with respect to the brand, to the change or the static behaviour is a pattern for brand communication. Brand communication has a number of features indicating its autonomy, complexity and versatility.

The brand is a factor in consumer behaviour management, whose behavioural responses are quite diverse and shaped by the social factors influence, the detection and taking into consideration of which affects the authenticity of the brand communication predicted effects. The most important feature of the brand is its psychology, although all marketing processes are aimed at its creation and development. When promoting the brand the expediency of integrated marketing communications is determined by the fact that the only advertising communications usage is not the main source of its meanings formation. In the vast majority of cases, modern brand communication can be characterized as integrated one. Since the effectiveness of brand management activities depends on the complex of integrated marketing communications, thus collectively providing a synergetic effect of brand communication. In the sphere of higher education the brand itself becomes a pledge of market competition power of higher education services, as choosing the university applicants in their choice mainly aim at the brand, reputation and image components of the higher educational establishment.

Brand communication is a social phenomenon, which includes advertising communications, that forms a desire to buy. Its effectiveness is achieved through advertising. Brand communication is a process of psychological impact on the communicator and the recipient, based on the mechanism of various social groups representatives' persuasion. Reasoning from the provision that brand communication is a social phenomenon, the brand is the image of a social object which occurs as a reaction to encouragement in the process of communicative interaction.

Key words: brand, brand communication, communication, brand's capital, marketing, advertising, social sphere. 


\title{
БРЕНД-КОМУНІКАЦІЯ ЯК СОЦІАЛЬНЕ ЯВИЩЕ
}

\author{
Михайло Поплавський \\ д-р пед. н., проф. \\ Київський національний університет культури і мистецтв \\ вул. Є. Коновальця, 36 \\ 01133, Київ, Україна \\ e-mail: pomm20180326@gmail.com \\ ORCID ID 0000-0002-8234-8064
}

Для бренд-комунікації закономірними є соціальна обумовленість об'єкта взаємодії, його емоційне оцінювання, а також мотивація до подальшої взаємодії стосовно бренда, до зміни або статичності поведінки. Бренд-комунікація має низку ознак, які вказують на їі автономність, складність і багатогранність.

Бренд - це чинник управління поведінкою споживачів, поведінкові реакції яких $\epsilon$ доволі різноманітними й формуються під впливом соціальних чинників, виявлення та облік яких впливають на достовірність прогнозованих ефектів брендкомунікації. Найважливішою властивістю бренда $\epsilon$ його психологічність, хоча такими є усі маркетингові процеси, скеровані на його створення і розвиток. При просуванні бренда доцільність застосування інтегрованих маркетингових комунікацій обумовлена тим фактом, що використання тільки рекламної комунікації не є основним джерелом формування його смислів. Сучасні бренд-комунікації в переважній більшості випадків можуть бути охарактеризовані як інтегровані. Ефективність діяльності з управління брендом залежить від комплексу інтегрованих маркетингових комунікацій, що в сукупності забезпечує синергетичний ефект бренд-комунікації. У сфері вищої освіти саме бренд стає запорукою конкурентоспроможності освітніх закладів на ринку освітніх послуг, адже, обираючи університет, абітурієнти у своєму виборі здебільшого орієнтуються на бренд, репутаційний та іміджевий складники закладу освіти

Бренд-комунікація - це соціальне явище, до якого належить і рекламна комунікація, що формує бажання купувати. Ефективність цього явища досягається завдяки рекламній діяльності. Бренд-комунікація - це також процес психологічного впливу на комунікатора та реципієнта, який грунтується на механізмі переконання представників різних соціальних груп. Виходячи з положення про те, що бренд-комунікація є соціальним явищем, відповідно бренд є образом соціального об'єкта, який виникає як реакція на заохочення в результаті комунікативної взаємодії.

Ключові слова: бренд, бренд-комунікація, комунікації, капітал бренда, маркетинг, реклама, соціальна сфера. 


\section{Relevance of the problem}

Today, the formation and further development of the brand is a priority in the activities of numerous companies, organizations and institutions, gaining new meaning in relation to individuals, ideas and various communities. This is especially important in the period of changing the social guidance and individual preferences, which raise the need to study brand and brand communication as a social phenomenon.

The problem formulation

The brand as a social phenomenon has recently been actively studied within brand management, in particular brand management activities, with communication with potential or actual consumers, customers, partners, and others being a part of these activities (Волков, 2006; LePla \& Parker, 2002; Nilsson, 1998; Thompson, \& Pringle, 1999). According to this kind of activity, brand management, or branding, is not restricted to communication, since it is directed to the process of forming consumer loyalty. Brand communication is a concept that along with the field of professional communication encompasses other communicative situations being discussed, in particular, in the field of consumer interpersonal communication. So, the brand communication should be understood as the message content and how it is delivered to the sender.

The state of the problem under research

Brand research is carried out in the context of various scientific paradigms, in particular, philosophical, cultural, psychological, sociological, marketing, linguistic, legal, etc. Usually, it is considered simultaneously from the marketing point of view (from the promotion standpoint) and management (from the managerial standpoint). The works of such scholars as D. Aaker, T. Ged, J.-N. Kapferer, P. Temporal, A. Ellwood, O. Shevchenko (Kapferer, 2008; Ellwood, 2000; Aaker, 1996; Temporal, 2002; Шевченко, 2012; Зозульов \& Нестерова, 2008) and others present brand in the context of its impact upon consumers. The context of the psychology of consumption, a significant contribution to the analysis of the brand is revealed in the works of E. Ilin, R. Blackwell, P. Miniard, D. Angel (Engel, Blackwell \& Miniard, 1990). It is synthesized in various communicative forms, in particular, advertising and public relations, as well as the basis of integrated marketing communications. The methodology of brand communication research is based on its theory and psychology, advertising communication psychology, the rhetoric of advertising, consumer behaviour theories, branding and marketing (Batey, 2008).

Unsolved issues

These authors' studies have not carried out the systematic understanding of the brand communication as a social phenomenon that requires additional study.

The purpose of the article is to clarify the meaning of the brand communication concept and its role in psychological impact upon the consumer. 


\section{Presenting the main material}

Modern studies of theory and sociology of communication are directed, first, to the study of communicative influence and interaction, communicative personality and its communicative competence, communication process modeling, analysis and systematization of existing models (H. Lasswell, C. Shannon, W. Weaver, Ch. Osgood, W. Schramm, R. Jacobson, T. Newcomb, F. Heider, etc.). The results of these studies make it possible to consider communication as a deliberate or unintentional transmission of meaning through a message. In this case, the most important problem of communication is the mechanism that translates the individual process of transmission and perception of information into social significance process of the personal and mass influences, embodied in the linguistic activity of individuals - the space of social norms and rules of communication realization (Конецкая, 1997, p. 6).

The basis of the psychological study of communication is the recognition of the fact that in every communicative process, according to Leontiev's concept, there is a certain unity of activity, communication and knowledge (Леонтьев, 2004). Classics of psychological science P. Zimbardo and M. Leippe rightly point out that the theory of communication deals mainly with the study of the structure and content of the process of transferring information as such. In contrast, social psychology focuses on what is happening inside a person's mind and the way his/her thoughts, feelings, and actions are influenced upon by other people (Zimbardo, \& Leippe, 1991). Thus, brand communication is a social activity by its essence. It is such a communicative activity of people, conditioned by a number of socially significant assessments, specific situations, communicative spheres and norms of communication adopted in a particular society (Конецкая, 1997, p. 6).

Brand communication is a kind of activity, with its subject being a brand that meets the specific needs of the target audience. The subject of the activity distinguishes one activity from another and guides it. According to $\mathrm{O}$. M. Leontiev, brand is a real motive of activity. The subject of the activity can be material and ideal, existing in perception and imagination only, or in the mind. The main thing is that there is always a necessity for it, as it always meets one or another need (Леонтьев, 2004, с. 80). Psychology is the most important feature of the brand: since it exists only in the minds of consumers, the psychological perception of a symbol, its evaluation and its role in the individual cognitive world picture - all these form and institutionalize the brand. The brand itself is already communication by itself, but in its minimal, reduced form: "through every touch point something about the brand is being communicated ... brand is never communicated. This is brand communication in its broadest, all-inclusive sense and it is what, over time, determines brand meaning” (Batey, 2008, p. 221). A known brand management specialist D. Aaker considers brand equity as a set of assets (or liabilities) associated with a brand name and a symbol that 
increases (or reduces) the value of a product or service to a firm and (or) clients of that firm (Aaker, 1996). According to D. Aaker, the main assets of the brand capital include awareness, loyalty, and brand quality, perceived and associated with it.

In particular, in the field of higher education, the use of branding gives the educational institution some benefits: the brand creates natural barriers for new competitors; the presence of a brand facilitates the "output" of new intellectual goods and services at the market; in a certain way, the brand also provides "protection" against market threats. A strong brand can help an educational institution to protect its market share without addressing to costly advertising campaigns and a large price cuts. Successfully branding its services, the institution differentiates them from competitors' ones in the eyes of target audiences. All this determines the analysis' relevance of the educational institutions practical experience in creating a brand and developing a suitable method in Ukraine. Today, the brand itself becomes a guarantee of their competitiveness in the market of educational services. When choosing a university, entrants are largely guided in their choice not by objective indicators of the educational institution activity (the quality of the teaching staff, the level of scientific research, etc.), but are oriented towards the brand, reputation and image components of the educational institution. That is why brand communication appeals not so much to rational thinking but to associative links, thus ensuring the emergence of the recipient's personal meanings, making him/her remember the main attributes of the brand. The latter are the functional or emotional associations bound with the brand, the emergence and effective consolidation of which are related to the basic brand characteristics (for example, the glorious history, unique features of the educational institution, innovative research, the latest technology, etc.). It is quite difficult to do in the process of educational institutions branding, taking into account their multifacet activities. Therefore, the task of managers is to develop such attributes that would provide the most positive assessment of the educational institution by different target audiences, which is impossible without a clear orientation and meeting their expectations. In this context, Kyiv National University of Culture and Arts is a vivid example. The University is a leader of education in Ukraine, one of the TOP-10 best cultural and artistic higher educational establishments in Europe. Its unique features are the most prestigious creative and business specialties, which have no analogues in Ukraine. In the period of turbulence in the educational market, Kyiv National University of Culture and Arts has chosen its own model and vector of development. Its future is leading lecturers, successful scholars and practitioners in particular field of activity, able to prepare students not for exams, but for life. The most important thing in the university is the atmosphere, the co-creation of students and teachers, instilling every student a belief in himself, to make it clear that he 
can do more than he thinks about himself (Поплавський, 2017, с. 453). The uniqueness is a main idea that Kyiv National University of Culture and Arts brings to the various target groups in the course of its positioning. As a part of its brand communication, the university focuses on traditions, the wellknown graduates, the lectures' high qualifications, freedom and democratic values in the process of learning and research.

The very sense of the brand communication is the interaction of the consumer with the brand. To designate a consumer-brand interaction unit, an acknowledged branding specialist, graduate of Oxford University M. Batey offers a "touch point" concept (Batey, 2008, p. 220). According to this concept, every case of consumer's contact with the brand, accompanied by the emergence of certain associations, can be considered as a "touch point"; it affects various perceptual and emotional levels and causes positive or negative reactions. Therefore, brand communication is social phenomenon by its essence. It is natural for it to be the social conditionality of the object of interaction, its emotional evaluation, as well as the motivation for further interaction in relation to the brand, to the change or the static behaviour. In other words, brand communication is intended to form the patterns of behaviour and people's activities, expressed in certain repetitive behavioural responses. Therefore, it should be convincing. While studying, it is necessary to take into account such communicative "components" of conviction as "communicator", "message" ("information"), "channel of transmission", "audience” (Myers, 2012).

The term "marketing communication" is semantically tangent to the notion of brand communication. Their interaction can be interpreted differently depending on the chosen point of view: in the narrow sense, they act as synonyms, but in the broader sense brand communication is a part of the marketing communications system (according to French marketing scientist J.-N. Kapferer, etc.). Nevertheless, the brand does not replace the marketing aimed at its promotion. The founder of the approach to the selection of marketing communications in a special field P. Kotler described the elements of the marketing communication process and actualized the question of its effectiveness. In his opinion, the communicator should operate according to the following scheme: to identify the target audience, determine the desired response, prepare an appeal to the audience, choose means of the information dissemination, find out the properties that characterize the sender, and get feedback (Kotler and Dubois, 1991). Therefore, marketers emphasize that all marketing processes, aimed at creating and developing a brand, are psychological by their nature.

Marketing communication covers different types of audiences and social groups. P. Kotler notes that the modern company manages a complex system of marketing communications. It is the company to communicate with its intermediaries, consumers and various contact audiences with its interme- 
diaries maintaining communication with their consumers and various contact audiences. Consumers are engaged in oral communication in the form of conversations and rumours with each other as well as with other contact audiences. At the same time, each group maintains a communication feedback with all others (Kotler \& Dubois, 1991, p. 408). It is worth noting that for modern marketing communications the consumption individualization processes are the key. Taking into consideration that marketing strategies are reoriented from the mass market to distinct individuals (Batey, 2008, p. 223), respectively, brand communication will develop through the individualization, adaptation of one idea to the perception of different consumers. This will allow to take into account the individual consumer needs, that is, to address the construct argumentation and to select the appropriate communication means. Simultaneously with the development of individually oriented marketing, there is a problem of "permitted" marketing, since not all consumers positively perceive to be brand-communication impacted on.

One of the main reasons for using marketing tools in education is its reform, directly affecting the development of competitive relations between educational institutions. This restructuring is connected, in particular, with the reduction of budget financing, a decrease in the number of school graduates, while the number of higher education institutions is increasing, as well as the current and future needs of the labour market. The solution of all these problems is impossible without further development of the theory and practice of the educational services marketing and the brand-technologies usage in the system of the educational institutions management. Therefore, Ukrainian educational institutions are increasingly turning their attention to the branding concept from the point of view of strengthening their image. However, the practical application of branding ideas generates a lot of new unresolved problems connected, as it was noted above, with the development of branding methodology, improvement of brand qualitative parameters, as well as the strengthening of its social and ethical potential.

Since the brand is created to optimize the consumption process, in this sense, the brand's psychology is bound to its effectiveness. In this regard, the notion of consumer loyalty to the brand draws much attention, as it is the key to branding and marketing paradigms (Kapferer, 2008; Aaker, 1996). In essence, loyalty is equated with efficiency. Loyal consumers are a special social group, whose behaviour depends on the brand's success and profitability. Consumer behaviour is defined as the actions of people when purchase, consume goods and services, as well as dispense with them (Engel, Blackwell \& Miniard, 1990). To a greater or lesser extent, consumer behaviour surveys provide an answer to the question why individuals are seeking to purchase certain goods. Therefore, it is no coincidence that the brand is investigated as a consumer behaviour factor, because "the consumer" is a 
role that the individual plays in a given situation. His/her behavioural responses are quite diverse and are shaped by the influence of social factors, the identification and taking into account of which contribute to greater reliability of the brand communication predicted effects.

In marketing theory and business practice, there is a special term used "integrated marketing communications". The centre of communications, the basis of their integration is the brand itself. The complex of integrated marketing communications includes traditional advertising, public relations, direct marketing, sales promotion, personal sales, e-marketing, sponsorship, event-marketing, and product placement. The expediency of using integrated marketing communications in brand promotion is stipulated to the recognition of the use of only advertising communications, traditionally being the main source of brand thinking, is currently to be insufficient. Nowadays fewer and fewer companies around the world are focusing their activities on the exclusive use of only one means of marketing communication. The effectiveness of brand management activities depends on the complex of integrated marketing communications, which collectively provide a synergetic effect of brand communication.

Integrated communications combine the possibilities of different types of communications (advertising, public relations, direct marketing, etc.) within a single communication strategy. Modern brand communication in the vast majority of cases can be characterized as integrated. The development of modern communication tools makes it possible to use not only traditional media and genres, but also interactive forms of interaction with the consumer (direct marketing, call centres, etc.), and so-called "new media" (via the Internet, mobile phones, videogames, iPods, digital media platforms, etc.). Therefore, brand strategies must meet a particular trend, because the specificity of brand communication determines the era of information and entertainment. The development of integrated communications is caused, first of all, by the emergence of new technical capabilities that affect the brand-communication content. This is, in particular, about social networks, with the branding objectives being defined in the following ways: strengthening the brand presence of educational institutions on social platforms; increase of the education institution website traffic; enhancing its positive image. In this aspect, the example of Kyiv National University of Culture and Arts, for which social networks became an indispensable tool of brand communication, is illustrative. The university's website is the main form of its Internet activity. It not only presents the university on the network, but also transmits its positioning strategy, provides basic information about its activities, forms and maintains a positive image of the institution, provides a feedback channel with entrants and students, promotes the advancement of educational services, and also builds effective communication with the scientific community within Ukraine and abroad. 
Using Internet technologies in the process of branding, it should be taken into account that all brand messages in the system of integrated marketing communications must be semantically linked. Integrated marketing communications create the company's image and the brand. They are directed at the consumer, being the centre of all marketing activity in order to meet his/her needs. In the integrated marketing communications, the idea of individual communication with the consumer is a fundamental one; different loyalty programs are developed for its implementation, etc. The importance of personalizing the brand is increasing nowadays, namely: for the consumer, the value of a brand being perceived by the influence of communication becomes more important than actual information.

Brand communication has a number of features that make it possible to speak about its autonomy, complexity and versatility. Since advertising is the most prominent form of integrated communications around the brand, there is an ungrounded point of view that brand communication and advertising communications are identical. Therefore, brand communication has all the characteristics inherent in advertising communications, in particular, such as mediation and mass character of influence (focused on a mass audience). However, brand communication is a wider social phenomenon, which includes not only advertising communications. Accordingly, it can be considered taking into consideration other parameters. Advertising communication is aimed at forming a desire to buy, and brand communication is to build social and psychological relations between brand-communicators and consumers. At the same time, the effectiveness of brand communication is achieved through advertising. To carry out the branding tasks is most consistent with symbolic metaphorical advertising, appealing to the intuitive level of consciousness. Also, one of the most important genre forms of the consumer interaction with the brand is the appearance of the branded product. Advertising forms a special relationship between the consumer and the brand. Respectively, advertising activity should be relevant to the brand and attractive to the consumer.

For the success of advertising, it is important to know how communicative messaging and brand are integrated into a creative content. If the link with the brand is weak, the consumer may remember the creative content, but he/she may not remember the brand or misinterpret it. Creativity and successive repetitions of the promotional messages strengthen the brand's positive associations. The advertising uses the brand's attributes being the company property: the corporate style elements, trademark (logo), etc. At the same time, the advertising scenes images can become the brand attributes - branded characters. Consequently, the brand communication to be effective, one must consider the synergy of the advertising product and its interpretation in the consumers' minds from their motivation, values, and desire point of view. In other words, the psychology of consumer motivation - on the one hand, - and the psychology of influence through 
discourse - on the other hand, - allow us to build a model, which makes the brand communication interpretation possible.

Advertising communication is considered among the factors that influence the consumers' behaviour (Фельсер, 2009). However, in modern business traditional means of brand promotion are constantly being reviewed. Advertising has the one-only justification - it is really a mega-trend in marketing, and it is called an identification of a brand or a trade mark's creation (Конецкая, 1997, с. 93). К. Kobjoll, a business consultant and the author of numerous books on marketing, believes that an advertisement is not aimed at attracting new customers, but to reinforce the convictions of those who have already bought the product that they did the right thing. He thinks that medium-sized entrepreneurs, not being able to make their products branded, need no advertising, they should address to such communication tools as public relations and sales promotion within the company. And these tools application will be more efficient. Nowadays, according to K. Kobjoll, the product promotion is associated with a "frenetic specialization", that is, specialization with a "maniacal obsession" in a certain niche (Kobjoll, 2000).

Conclusions

Thus, we can conclude that brand communication is a process of social and psychological impact on a communicator and a recipient, based on the mechanism of different target audience representatives' persuasion. Thus, based on the notion, brand communication is a social phenomenon, a special type of social communication. It is implemented as a process of interaction, changing motives, attitudes, behaviour and social groups activities, consequently forming an appropriate brand's image as a social object. Brand is an image that emerges as a reaction to encouragement as a result of communicative interaction.

Further research of brand communication envisions further study of consumer motivation issues; consideration of the brand from the point of view of social attitudes formation; extension of the persuasion and social influence mechanisms in brand communication; identification of the subjects' interaction specifics in brand communication, as well as analysis of educational institutions branding strategies, their brand attributes, etc.

\section{ЛIТЕРАТУРА}

Волков, А. Т. (2006). Стратегический бренд-менеджмент и капитализация организации. Москва.

Зозульов, О. \& Нестерова, Ю. (2008). Бренд як нематеріальний актив у постіндустріальному суспільстві. Економіка України. № 3. С. 4-11.

Конецкая, В. П. (1997). Социология коммуникации. Москва: Международный университет бизнеса и управления.

Леонтьев, А. Н. (2004). Деятельность. Сознание. Личность. Москва: Смысл: Издательский центр «Академия». 
Поплавський, М. М. (2017). Ректор. Київ: Р. К. Майстер-принт.

Фельсер, Г. (2009). Психология потребителей и реклама. Харьков: Издательство «Гуманитарный центр».

Шевченко, О. Л. (2012). Маркетингові комунікації та їхня роль у процесах створення бренду. Взято 3 : http://ena.lp.edu.ua/bitstream/ntb/17088/1/280Shevchenko-455-457.pdf

Aaker, D. (1996). Building Strong Brands. New York: The Free Press [in English].

Batey, M. (2008). Brand meaning. New York: Routledge [in English].

Du Plessis, E. (2005). The Advertised Mind: ground-breaking insights into How Our Brains Respond to Advertising. London: Kogan Page [in English].

Ellwood, I. (2000). The essential brand book. Over 100 Techniques to Increase Brand Value. London: Kogan page [in English].

Engel, J. F., Blackwell, R. D. \& Miniard, P. W. (1990). Consumer behavior. 6th ed. Chicago: Dryden Press [in English].

Kapferer, J.-N. (2008). New strategic brand management: creating and sustaining brand equity long. 4th ed. London: Kogan page [in English].

Kobjoll, K. (2000). Motivaction: Begeisterung ist ubertragbar. Zürich: Orell Füssli [in German].

Kotler, P. \& Dubois, B. (1991). Marketing Management. Paris: Publi-Union [in English].

LePla, F. J. \& Parker, L. M. (2002). Integrated Branding. 2nd ed. London: Kogan Page [in English].

Myers, D. G. (2012). Social psychology. 11th ed. Boston: MA: McGraw-Hill [in English].

Nilsson, T. (1998). Competitive branding: Winning in the Market Place with Value-Added Brands. 1st ed. Chichester: John Wiley [in English].

Temporal, P. (2002). Advanced brand management: from vision to valuation. Singapore: John Wiley \& Sons [in English].

Thompson, M. \& Pringle, H. (1999). Brand spirit: How couse related marketing builds brands. Chichester: Wiley [in English].

Zimbardo, P. G., \& Leippe, M. R. (1991). The psychology of attitude change and social influence. New York: McGraw-Hill [in English].

\section{REFERENCES}

Aaker, D. (1996). Building Strong Brands, New York: The Free Press [in English].

Batey, M. (2008). Brand meaning. New York: Routledge [in English].

Du Plessis, E. (2005). The Advertised Mind: ground-breaking insights into How Our Brains Respond to Advertising. London: Kogan Page [in English].

Felser, G. (2009). Psikhologiia potrebitelei i reklama [Consumer psychology and advertising]. Kharkov: Izdatelstvo "Gumanitarnyi tsentr" [in Russian].

Kobjoll, K. (2000). Motivaction: Begeisterung ist ubertragbar. Zürich: Orell Füssli [in German].

Konetskaia, V. P. (1997). Sotsiologiia kommunikatsii [Sociology of communication]. Moscow: Mezhdunarodnyi universitet biznesa i upravleniia [in Russian].

Leontev, A. N. (2004). Deiatelnost. Soznanie. Lichnost [Activity. Consciousness. Personality]. Moscow: Smysl, Izdatelskii tsentr Akademiia [in Russian].

Ellwood, I. (2000). The essential brand book. Over 100 Techniques to Increase Brand Value. London: Kogan page [in English]. 
Engel, J. F., Blackwell, R. D. \& Miniard, P. W. (1990). Consumer behavior. 6th ed. Chicago: Dryden Press [in English].

Kapferer, J.-N. (2008). New strategic brand management: creating and sustaining brand equity long. 4th ed. London: Kogan page [in English].

Kotler, P. \& Dubois, B. (1991). Marketing Management. Paris: Publi-Union [in English].

LePla, F. J. \& Parker, L. M. (2002). Integrated Branding. 2nd ed. London: Kogan Page [in English].

Myers, D. G. (2012). Social psychology. 11th ed. Boston: MA: McGraw-Hill [in English].

Nilsson, T. (1998). Competitive branding: Winning in the Market Place with Value-Added Brands. 1st ed. Chichester: John Wiley [in English].

Poplavskyi, M. M. (2017). Rektor [Rector]. Kyiv: Maister-prynt [in Ukrainian].

Shevchenko, O. L. (2012). Marketynhovi komunikatsii ta yikhnia rol u protsesakh stvorennia brendu [Marketing communications and their role in the processes of brand creation]. Retrieved from: http://ena.lp.edu.ua/bitstream/ntb/17088/1/280-Shevchenko-455-457. pdf [in Ukrainian].

Temporal, P. (2002). Advanced brand management: from vision to valuation. Singapore: John Wiley \& Sons [in English].

Thompson, M. \& Pringle, H. (1999). Brand spirit: How couse related marketing builds brands. Chichester: Wiley [in English].

Volkov, A. T. (2006). Strategicheskii brend-menedzhment $i$ kapitalizatsiia organizatsii [Strategic brand management and organization capitalization]. Moscow [in Russian].

Zimbardo, P. G., \& Leippe, M. R. (1991). The psychology of attitude change and social influence. New York: McGraw-Hill [in English].

Zozulov, O. \& Nesterova, Yu. (2008). Brend yak nematerialnyi aktyv u postindustrialnomu suspilstvi [The brand as an intangible asset in a post-industrial society]. Ekonomika Ukrainy. № 3. pp. 4-11 [in Ukrainian]. 